\title{
Introduction
}

\section{A media history of war remains}

\author{
Marie Cronqvist \& Lina Sturfelt
}

\begin{abstract}
Once there was a shock
that left behind a long, shimmering comet tail. It keeps us inside. It makes the TV pictures snowy. It settles in cold drops on the telephone wires.

Tomas Tranströmer, 'After a death' (1966) ${ }^{1}$
\end{abstract}

What remains with us after somebody's death? In a poem from 1966, the Swedish poet and future Nobel laureate Tomas Tranströmer reflected on the 'long, shimmering comet tail' that the shock leaves behind, and which 'keeps us inside'. Death has a comet tail, a tendency to remain with us, sometimes for a very long time. Tranströmer also uses references to different media-the television, the telephone wire-to enforce the image of how communication is somehow broken or challenged. To communicate the meaning of death is not only a complex and challenging enterprise, it is also largely dependent on the materialities of media.

This book is about the mediations and sense-making narratives of war deaths and suffering. In the first half of the twentieth century, more than 120 million people died an untimely or violent death-on the battlefield, in concentration camps, through fierce air strikes, or as casualties of the many severe epidemics and hardships that followed on the heels of war. The experiences and narratives of war that flowed through the different media of the time were often focused on the emotional, the personal, the everyday, and the subjective. War, shock, and trauma also lived on in the stories, sometimes to a remarkable 
extent, once the years of conflict were replaced by peace and prosperity. The displaced remains of bodies and the reminiscences of personal or collective suffering lingered on as sad mementos in the culture of the everyday. They settled 'in cold drops on the telephone wires'.

The experience of twentieth-century warfare not only flowed through different media of the time, however. Its legacy is still very much with us today, framing our understanding of war, conflict, and suffering. In this way, the findings in this book are not merely about past events, but also about the present and the future. Stories of death are always more about the living than the dead. Through mediated memories, we are immersed in the struggle to make sense of our troubled past, and the remaining narratives and images of death and suffering are transmitted and echoed in our understanding of contemporary conflicts.

In this volume, we present a collection of long-lived media representations and narratives. The fact that they were anchored in various media forms has determined our unwavering focus on a range of media, which all communicated the realities of war. ${ }^{2}$ Our thesis is that in the period roughly covering the 1910s to the 1970s, diverse forms of cultural production-newspapers, film, television, and radio, but also commemorative rituals, fiction, music, comic books, and monuments-repeated, reinforced, or renegotiated people's beliefs about war experiences, turning the terror and trauma of war into stories that could be situated within the conventions of public display.

Mediations of war, suffering, and death are at the heart of the book, but we also go beyond the study of mere representation to ground our analysis in both genre and media form. The contributors represent a variety of scholarly fields-history, human rights studies, media history, film studies, cultural studies, comparative literature, publishing studies, and rhetoric - and the primary sources analysed in the chapters range from anti-war fiction in the First World War, interwar and post-war reportage, radio war correspondence, and film documentaries in the aftermath of the Second World War, to Cold War comic books and men's magazines. By drawing on a diverse range of sources and empirical examples, we set out to compare different forms of media and expression over an extended period. With the varied cases represented here, we want to demonstrate that the horror of war is hard to conceive of but through its mediations. 
This edited volume is inspired by different vibrant research fields, each of them rich in scope. Those we have singled out as particularly important are discussed in this introduction: the cultural history of war, and sensing and mediating war. We cannot hope to cover these fields in their entirety, of course, nor would we claim that they are unrelated, or by placing an emphasis on these two particular questions that we mean to ignore the obviously relevant field of historical memory studies. Quite the contrary, as will become apparent, memory is a crucial dimension, and we owe a debt of thanks to seminal works on the memory of the world wars in several European countries. ${ }^{3}$ Yet to this vast and thoroughly researched field of war and cultural memory, our contribution is to add an interdisciplinary discussion that focuses more specifically on media specificity and the history of human sensation.

\section{The cultural history of war}

In recent decades, the cultural history of war has become one of the most dynamic and inventive fields of historical scholarship. Cultural historians have appropriated the theme of war, broadening the often static and narrow view of war and militarism that long characterized military history. Scholars such as Joanna Bourke, Jay Winter, Omer Bartov, Stéphane Audoin-Rouzeau, and Annette Becker have substantially changed our understanding of the history of war and violence in the twentieth century by offering new perspectives. ${ }^{4}$ Today, the cultural history of war and warfare has developed into a vast and truly interdisciplinary field, drawing insights and methods from disciplines as diverse as anthropology, literary and visual studies, media studies, memory studies, and lately archaeology and cultural geography.

Suffice to say, the present volume is very much part of this new tradition, and we are all in some way indebted to the cultural approaches to the study of war represented by series such as Studies in the Social and Cultural History of Modern Warfare (Cambridge University Press), which focuses on 'the social and cultural history of armed conflict, and the impact of military events on social and cultural history' from the 1850 os to the present day, and the Cultural History of Modern War (Manchester University Press)—associated with the 
Cultural History of War Group at the Centre for the Cultural History of War at Manchester University-which interrogates the divisions between war and society, war and peace, allies and enemies, heroes and villains ... maintaining a focus on the cultural meanings of the myriad practices of modern war. ${ }^{5}$ Another constant source of inspiration has been the work of the Group for War and Culture Studies based at the University of Westminster since 1995, and their important publication War and Culture Studies (2007-), an interdisciplinary journal that 'emphasises cultural histories and cultural production as significant forces that have shaped experiences, representations and memories of war, with a specific focus on the relationship between war and culture in the modern era. ${ }^{6}$

Like the contributions to the present volume, much of this research is preoccupied with the lasting cultural impact of the world wars or the era of total war. Following Nicholas J. Saunders and Paul Cornish, we would argue that 'the industrialized nature of twentieth-century war was a unique cultural phenomenon, in possession of a material and psychological intensity that embodies the extremes of human behaviour, from total economic mobilization to the unbearable sadness of individual loss.7 It has profoundly shaped the ways conflicts are imagined and remembered, and framed the language we use to describe traumatic memories. ${ }^{8}$ However, counter to the overwhelmingly British, German, and French cultural histories of war, we offer new and detailed empirical analyses of hitherto under-researched or overlooked primary sources for this particular period. Some of the chapters examine Swedish examples of mediated experiences and memories of death and suffering by using findings that are unfamiliar to international audiences. Still, it should be noted that all the chapters even so deal with European or Western narratives of war and suffering.

While total war scarred entire societies-and all media obviously played an important role in totalizing war as a common experience and in blurring the lines between 'front' and 'home front', 'civilian' and 'combatant' - it is important to bear in mind that the way war is mediated is also shaped by social institutions and social experience, reflecting a 'politics of the senses'. As Christine Sylvester has pointed out, the question of who is seen and heard in the media, whose stories are told, does matter. ${ }^{9}$ In the present volume, we hold to a broad concept 
of war and what counts as 'war experience', paying special attention to both civilian testimonies and the representations and mediations of women and children (in the chapters by Qvarnström, Sturfelt, Skoog, Bergström, and Cronqvist), and to the soldiers' stories and the more traditional battlefield narratives (Kärrholm and Saarenmaa).

Another lasting response to the traumas of total war has been the rise of human rights as law, politics, and rhetoric. The link between the world wars, the Holocaust, and human rights is often taken for granted rather than scrutinized, but as Åsa Bergström and Lina Sturfelt show in their chapters, 'the age of catastrophe' also resulted in new kinds of humanitarian reporting, which served as an emotive and ritual response to the disasters of war. Their contributions call for the interdisciplinary field of human rights studies to pay closer attention to historical context, but above all to pay greater heed to recent developments in media studies and theory. ${ }^{10}$ In which ways has the history of human rights and humanitarianism been entangled in the history and memory of the world wars and its mediations? What narrative forms and specific media have favoured such a development? ${ }^{11}$

\section{Sensing and mediating war}

In the cultural study of war and violence, the examination of human experience and emotion has played an important part. Over the past decade, there have been attempts to rethink the genealogy and ontology of war by factoring in the sensory dimension. Feminist international relations scholars in particular have argued for an understanding of war as experienced and sensed. ${ }^{12}$ This shift requires us to place the body at the centre of any war analysis in order to understand both the social institutions and individual experiences of war. In the end, as Sylvester writes, war is experienced through the body, both physically and emotionally, which is why Kevin McSorley argues that the body should be central to our thinking about war, recognizing 'the countless affective, sensory and embodied ways through which war lives and breeds. ${ }^{13}$ Critical of most of the conventional 'body-absent' war scholarship, and indeed the Clausewitzian paradigm that war is just politics by any other means, McSorley instead suggests that we should explore war as 'politics incarnate, politics written on and experienced 
through the thinking, feeling bodies of men and women. ${ }^{14}$ This entails an explicit focus on war's many sensory practices, and the ways in which war is prepared, enacted, and reproduced in embodied action, suffering, and memory. As McSorley notes, 'an analytical focus upon the body tends to render any clear demarcations of war zones and times problematic, emphasizing instead the enactment and reproduction of war through affective dispositions, corporeal careers, embodied suffering and somatic memories that endure across time and place. ${ }^{15}$ In a recent example, which like us concentrates on the world war era and on war's material and affective remains, Modern conflict and the senses (2017) investigates 'the sensual worlds created by modern war, focusing on the sensorial responses embodied in and provoked by the materiality of conflict and its aftermath. ${ }^{16}$

The present collection of chapters also takes the line that 'the nodal role of the body as a trans-disciplinary means of analysis and understanding' war and its human consequences is the way forward, albeit with a nod to the embodied, sensory experiences of different media, such as radio (Skoog) or comic books (Kärrholm). ${ }^{17}$ In war stories, the dead or deformed body was frequently used to invite the reader, viewer, or listener to reflect on the meaning of war, often combined with an anti-war message or the issue of responsibility (Qvarnström, Sturfelt, and Kärrholm). Others also used the body of the reporter as a medium to convey certain emotional responses to the suffering of war (Sturfelt). While some media, such as men's magazines, stressed information, the broad picture, and engagement as a 'male' way of taking pleasure in war (Saarenmaa), humanitarian reporting might emphasize empathy and compassion (Sturfelt), and short stories, literary reportages in the weekly magazines, or comic books might concentrate on the horror and outrage of war (Qvarnström, Cronqvist, and Kärrholm).

Another choice we have made, which resonates with the wider research on war and culture, is to give priority to the visual. Despite the media forms analysed here we have all found that sight was very much the privileged sense when it came to narrating and remembering the emotional and sensory experiences of twentieth-century warfare. The many testimonies are all in some way focused on the visual, on 'seeing' suffering, either literally or metaphorically. Practices of looking 
and the importance of the visual in connection with violence and war are something that have been thoroughly investigated by a number of media scholars in recent years, highlighting the role of a variety of media in challenging or reinforcing war experiences. Not least, analyses of the role of photojournalism have raised the question of possible 'compassion fatigue' in the Western media and the chances of instilling a new ethical sensibility for what Lilie Chouliaraki calls 'distant sufferers.' ${ }^{18}$ Also, as Ekaterina Balabanova and Katy Parry rightly point out in their introduction to a special issue on communicating war in the Journal of War and Culture Studies, there is a need to further explore the visual construction of war narratives in media forms, because in moving away from the traditional focus on news to concentrate on other forms of popular culture, visual culture, or activist media, we can at last investigate how alternative media forms and actors are able to challenge preconceptions of legitimate voices in the "storytelling" of war experiences. ${ }^{19}$ This invites us to consider which representations and forms of remembrance become dominant, and which are contested, adjusted, or resisted. These dimensions are discussed in several of the chapters in this book (Sturfelt, Skoog, Kärrholm, and Saarenmaa).

This also taps into the broader discussion about the role of the media in the processes of commemorating war and suffering. The memory dimension runs through all the chapters in this volume, and some (Skoog, Cronqvist, and Saarenmaa) have chosen to foreground the issue. Alongside the broad research field of collective or cultural memory, there is now a new, vibrant field directly concerned with media and memory, including, for example, journalism, film, and digital media. Some of its scholars, indeed, have focused specifically on the memory of violence and war in recent times. ${ }^{20}$ Nevertheless, there seems to be a peculiar lack of connection here between historical studies and media studies of memory. In media studies, the focus is more often than not on aspects of digital memory in the new media age, sometimes to the neglect of the long historical tradition of memory studies, while the mere concept of media or the mediation of memory remains heavily under-theorized by historians. ${ }^{21}$ This book is an effort to bridge the gap between the two research fields, converging on the interdisciplinary field of media history. 
In contrast to these earlier monodisciplinary studies of memory, then, we present a selection of cases, all of which highlight media specificity and the importance of media forms to the portrayal of war, suffering, and death, as well as the manifestations of war memories. It has been important for us to identify the various strands of narrative or storytelling that a specific medium lends itself to-be it the comic book, the documentary film, the reportage, the photograph, the musical work, the monument, or any other form of cultural production. Which war narratives are unique to which medium, and how can a historically sensitive analysis take such media specificity into account? In their plea for a 'media-conscious narratology', Marie-Laure Ryan and Jan-Noël Thon argue that media forms are key in the construction of narratives, for they affect their content, presentation, and reception. ${ }^{22}$ This leads us to the important issues of how the inherent characteristics of a medium shape the narrative, and how narratives change and produce new meanings in the process of migrating to another medium. In her chapter, Sofi Qvarnström probes the issue of media specificity. What are the possibilities and limitations of a given medium? And what happens to war narratives as they cross from one medium to another?

The answer to such questions, we would argue, has to be anchored in a historical context. Viewed through the lens of media history, this book offers a novel understanding of war narratives and how they have operated in the media. Like Roger Silverstone, we use the term mediation in order to highlight the interplay between media as technology and media as discourse, text, narrative, and content. ${ }^{23}$ The materiality and temporality of the media form are two such dimensions; for example, in their contributions, Qvarnström and Kristin Skoog reflect on 'slow' versus 'rapid' media in the shape of literary novels and the radio respectively. Our conscious choice of 'mediation' is not meant to oppose any possible inquiries into the 'mediatization of war'; it is simply to say that the following essays are more in line with Silverstone's and others' emphasis on 'the heterogeneity of the transformations to which media give rise across a complex and divided social space' rather than a meta process of a cumulative kind. ${ }^{24}$

Our findings also shed light on the public's role in the making and remaking of war narratives and war memories, and the entangled 
relationship between media creators and media consumers. Media such as the comic book, discussed by Sara Kärrholm, show evidence of the collaborative relationships formed between editorial boards and the readers. Form and content were necessarily brought together in order to draw readers into a dialogue on the meaning of war, inviting them to take an active role in the genesis of the story and to share the symbolic representation of the events. A similar focus on the public's collaboration was evident from humanitarian reporting, where form and content were engineered to make the reader react and act, for example by making charitable donations (Sturfelt and Bergström). Considering the growing interest in participatory or collaborative media in a broad range of disciplines, frequently against the background of so-called new or interactive media, it is salutary to note that historical perspectives and analyses can confirm that such participatory media are nothing new. ${ }^{25}$

The important question here is to ask how a medium mediates - that is, reconciles-different cultural, political, and economic forces. All the chapters raise key questions about the possibilities and limitations of any given medium. In what way do social actors operate within, or in opposition to, media structures? What is the role of media agents, organizations, and institutions? The concept of mediation in this book can in some senses be related to the resolution or settling of differences. We see war storytelling as an expression of such a 'working through' or 'settling' cultural practice. The mediator or medium acts to reconcile different parties or opposites, in the present instance between the everyday and the horrors of war. The mediation of war is an appropriation of violence and death into people's lives, but it also engages with otherness and, as such, it brings to light the ethical underpinnings of mediation that Silverstone calls 'proper distance. ${ }^{26}$

Ultimately, this again brings to mind a simple but important point, one which Richard Huntington and Peter Metcalf have made: stories about death are less about the dead than about the living. They are communicative practices that connect to cultural and religious values and rituals. ${ }^{27}$ Similarly, Thomas W. Laqueur argues that the dead body serves a fundamental need for the living; 'the work of the dead' is to engender human communities that connect the past to the future. ${ }^{28}$ Translated into the language of this book, the dead body is a medium 
that makes it possible for the living to work through and communicate pain, agony, and grief. It is about war remains, literally as well as figuratively.

\section{The outline and content of the book}

The contributors represent a variety of scholarly fields, reflecting a conviction that the complexities of the world war era and its mediations call for a fully interdisciplinary approach. Although many of the examples are taken from a Swedish empirical context, the primary aim is not to present a specifically Swedish or Nordic experience, but to highlight the narrative structures and genres, and the significance of different media forms, in public representations of war violence and death. Nevertheless, we would argue that the many Swedish examples bring another geocultural element to the scholarship on war remains, a much-needed corrective in a field very much dominated by German, French, and British perspectives. To that end, the book is arranged chronologically, beginning with the seminal catastrophe of the First World War and ending with memories of the Second World War in a seventies Cold War context.

Sofi Qvarnström uses the First World War short stories of the Swedish pacifist writer Anna Lenah Elgström to investigate how the special characteristics of the literary novel as a slow, resilient medium shaped representations of war, death, and suffering. Elgström's fiction was highly visual and emotional, and often focused on the suffering body. Her narratives highlighted the sufferings of women and children in total war, equating the home front with the battlefront as an arena of war. In her anti-war journalism, she pursued a female pacifism based on ideas of maternity as a way to peace, but, as Qvarnström shows, Elgström's fiction opened up for far more complex, ambiguous, and often pessimistic narratives on the subject of war than her journalistic work allowed for.

Lina Sturfelt analyses the practices of sensing and seeing total war in the humanitarian reporting and media campaigns of Rädda Barnen (Swedish Save the Children, or RB) in the aftermath of the First World War, focusing on the organization's strategic uses of emotional and sensory representations of the war child's body. By examining both 
textual and visual narratives in the daily and weekly Swedish press, Sturfelt investigates why and how the RB invested in a certain moral rhetoric of seeing and sensing suffering in order to ameliorate it, showing that a visual/visualizing discourse was key to their interwar humanitarian imagery. When framing hunger as 'war news', the starving body served as a reminder of its horrors, but also of the possibility for compassionate action. By envisioning children's bodies as both temporally and spatially afflicted by war, the traumatic memory of total war was visualized for a Swedish audience, challenging the more conventional war narratives. Acknowledging their embodied suffering was also a way of recognizing and taking responsibility for the wider consequences of war's victimization of (European) humanity.

Kristin Skoog then explores the embodied and sensory experience of war in a study of radio reporting during the Second World War, using the case of the BBC's war correspondent Audrey Russell. Drawing on recent scholarship, Skoog introduces sensory culture and sensory history to the study of mainstream radio and media history. Radio transformed the way war was mediated, and, as Skoog argues, radio war reporting should be thought of as offering a multilevel sensory experience that created a sense of immediacy, intimacy, and presence, changing listeners' perception of proximity and distance. In contrast to a slow medium such as the literary novel, radio was thus a rapid, immediate medium. By focusing on Russell's wartime experiences, Skoog further shows that the way war is mediated and represented by social institutions and social experience undoubtedly produces a 'politics of the senses', which in this case was clearly shaped by gender and the gendered body.

The focus then shifts to the post-war era, and from radio to film. Åsa Bergström investigates the organization Svenska Europahjälpen (Swedish European Aid, or SE), which existed between 1946 and 1951 to raise money for European refugees. During its brief existence, the SE commissioned a number of promotional short films to convince audiences to donate to its relief work. These films primarily focussed on Rädda Barnen (Swedish Save the Children), an organization that is still active today, promoting it as an active helping hand and Sweden as a nation of good-hearted heroes. Pre-production scripts and the films themselves reveal a degree of strategic media awareness, which 
Bergström uses to chart the SE's development and its media strategies, and relate them to more general representations of trauma and personal testimony.

Literary journalism is another narrative genre of war, and the magazine is one of the main media forms through which it finds its audience. The journalistic reporting of atomic warfare is addressed by Marie Cronqvist, who looks at the American writer and war correspondent John Hersey's classic reportage 'Hiroshima', published in the New Yorker in August 1946. This famous piece has been thoroughly investigated by researchers over the years, but Cronqvist offers a new reading by connecting Hersey's thoughts on journalistic mediation to Geraldine Muhlmann's concept of journalism's decentring tendencies. She shows how 'Hiroshima' should be read in the light of recent scholarship on journalism, memory, and grief, and argues that from a present-day perspective it is with such voices of the other, with journalism that decentres rather than unifies, that the pervasive and destructive media discourse of fear that is the curse of contemporary journalism about mass atrocities can be challenged.

Another widely popular but seldom-analysed medium of war experience is the comic book. Sara Kärrholm explores media-specific aspects of the American EC Comic's fifties war comics. Media specificity conditioned the comics' central message, which was to show the horrors of war-a subversive message at the time of publication. Kärrholm shows that the interplay between text, image and context, in the form of paratexts, is crucial for any understanding of EC's war comics. She shows how EC used a specific motif, the dead body, and its framing in the layout of the comic, to reinforce the central message of the various paratexts of the print comics. Form and content were used in unison to draw readers into a dialogue about the meaning of war, and to provide what was deemed the correct framing for an interpretation not only of the Korean War in the years 1950-1953, but also of the recent experiences of the Second World War.

Laura Saarenmaa then discusses the seemingly endless recirculation of memories of the Second World War and Nazi atrocities among mass readerships. These are now the stuff of popular history magazines, whereas in the sixties and seventies these kinds of materials circulated primarily in men's magazines, sandwiched between nude 
pin-ups and articles about sex. Saarenmaa approaches the circulation of Nazi imagery as a source of pleasure and excitement that found parallels in pornography. Driven by the intermediation from older to younger generations, the Nazi stories produced biased historical knowledge by focusing on the personalities of the Nazi officers rather than their victims. Moreover, Saarenmaa argues that in the particular context of sixties and seventies Sweden, this recirculation was linked to the state of the world, and especially to political tensions, wars, and armed conflicts.

Finally, in a short postscript, we editors present the five key findings of the volume and their consequences for further research, returning to the benefit of adopting a historical perspective on the mediation of war remains, especially for the understanding of war trauma in our own time.

The structure of this volume may be chronological, moving from the 1910 s to the 1970s, but this does not mean that the cases studied here merely deal with past events. They are also concerns of the present. Several of the chapters concern what might best be called generational layers of remembering war and suffering. As the authors stress, war stories find new meanings whenever they are reread, reheard, or reseen by new generations, be it Elgström's short stories from the First World War, Hersey's journalistic account of the atomic bombing of Hiroshima, or the circulation of images of Nazi perpetrators and weapons in today's history magazines. When, where, and how is it even possible to represent traumatic events? Using a range of examples, we all argue that rather than seeing war representations in terms of clear, distinct phases or genres, we should consider how they appear, fade, and reappear in different media forms, and the representational consequences of such transformations. Ultimately, the reason to revisit the era of total war is that it still matters. Its shockwaves are with us even now.

\section{Notes}

1 Robert Bly, The half-finished heaven: The best poems of Tomas Tranströmer (Saint Paul: Graywolf, 2001), 28.

2 Although the chapters in this book focus on some of the possible media forms that communicated war experiences, we work with a very broad definition taken from the cultural history of the media. See Peter Burke \& Asa Briggs, A social history of 
the media: From Gutenberg to the Internet (Cambridge: Polity, 2009); Lisa Gitelman, Always already new: Media, history, and the data of culture (Cambridge, Mass.: MIT Press, 2006); Solveig Jülich et al. (eds.), Mediernas kulturhistoria (Stockholm: Statens ljud- och bildarkiv, 2008); Marie Cronqvist et al. (eds.), Mediehistoriska vändningar (Mediehistoriskt arkiv, 25; Lund: Lunds universitet, 2014).

3 Among the many valuable works covering a range of countries, are the following from the UK, France, Germany, and Scandinavia: Jay Winter, Sites of memory, sites of mourning: The Great War in European memory (Cambridge: CUP, 1995); Pierre Nora, Les lieux de mémoire, 3 vols (Paris: Gallimard, 1984-6); Monika Flacke (ed.), Mythen der Nationen: 1945-Arena der Erinnerungen: Eine Ausstellung des Deutsches Historisches Museums, 2 vols (Berlin: Deutsches Historisches Museum, 2004); Klas-Göran Karlsson \& Ulf Zander (eds.), Echoes of the Holocaust: Historical cultures in contemporary Europe (Lund: Nordic Academic Press, 2003); Claus Bryld \& Anette Warring, Besattelsetiden som kollektiv erindring (Roskilde: Roskilde Universitetsforlag, 1999).

4 Joanna Bourke, Dismembering the male: Men's bodies, Britain and the Great War (Chicago: University of Chicago Press, 1996); Joanna Bourke, An intimate history of killing: Face-to-face killing in twentieth-century warfare (London: Basic, 1999); Joanna Bourke, Deep violence: Military violence, war play, and the social life of weapons (Berkeley: Counterpoint, 2015); Winter 1995; Jay Winter (ed.), War and remembrance in the twentieth century (Cambridge: CUP, 1999); Jay Winter, Remembering war: The Great War between memory and history in the 2oth century (New Haven: Yale University Press, 2006); Jay Winter et al. (eds.), Shadows of war: A social history of silence in the twentieth century (New Haven: Yale University Press, 2010); Omer Bartov, Mirrors of destruction: War, genocide, and modern identity (Oxford: OUP, 2002); Stéphane Audoin-Rouzeau \& Annette Becker, 14-18: Understanding the Great War (New York: Hill \& Wang, 2002); see also Martin Evans, 'Opening up the Battlefield: War Studies and the Cultural Turn', Journal of War \& Culture Studies, 1/1 (2007), 47-51.

5 Studies in the Social and Cultural History of Modern Warfare, www.cambridge. org (accessed 20 Dec. 2017); Cultural History of Modern War, www.manchesteruniversitypress.co.uk (accessed 20 Dec. 2017).

6 'Journal of War and Culture Studies: Aims and Scope', www.tandfonline.com (accessed 20 Dec. 2017). See also Debra Kelly, 'Editorial: War! What is it good for? The work of the Group for War and Culture Studies', Journal of War \& Culture Studies, 1/1 (2007), 3-7.

7 Nicholas J. Saunders \& Paul Cornish (eds.), Modern conflict and the senses (Abingdon: Routledge, 2017), i.

8 Winter 2006, 1, 44.

9 Christine Sylvester, War as experience: Contributions from international relations and feminist analysis (London: Routledge, 2013), 1-6.

10 Studies of human rights and the media have long concentrated on freedom of speech, media legislation, and human rights reporting - usually with a contemporary, non-historical perspective. Perspectives informed by media theory, media system analyses, or the cultural history of the media have only recently begun 
to influence the field. See, for example, Lieve Gies, Mediating human rights: Media, culture and human rights law (Abingdon: Routledge, 2014); Ekaterina Balabanova, The media and human rights: The cosmopolitan promise (London: Routledge, 2014); Susana Sampaio Dias, Reporting humans rights (New York: Peter Lang, 2016).

11 See Lynn Hunt, Inventing human rights: A history (New York: W. W. Norton, 2007); James Dawes et al., 'On narrative and human rights', Humanity, 5/1 (2014), 149-56; Sharon Sliwinski, Human rights in camera (Chicago: University of Chicago Press, 2011); Heide Fehrenbach \& Davide Rodogno (eds.), Humanitarian photography: A history (Cambridge: CUP, 2015).

12 Christine Sylvester (ed.), Experiencing war (London: Routledge, 2011); Sylvester 2013; Laura Sjoberg, Gendering global conflict: Towards a feminist theory of war (New York: Columbia University Press, 2012); Laura Sjoberg, Gender, war and conflict (Cambridge: Polity, 2014); Cynthia Enloe, Nimo's war, Emma's war: Making feminist sense of the Iraq War (Berkeley \& Los Angeles: University of California Press, 2010); Judith Butler, Frames of war: When is life grievable? (London: Verso, 2009).

13 Sylvester 2013; Kevin McSorley, 'War and the body', in id. (ed.), War and the body: Militarisation, practice and experience (London: Routledge, 2013), 1.

14 McSorley 2013, 1.

15 Ibid. 2.

16 Saunders \& Cornish 2017.

17 Dan Trodman, 'Foreword', in Nicholas J. Saunders \& Paul Cornish (eds.), Bodies in conflict: Corporeality, materiality, and transformation (New York: Routledge, 2014), xvi.

18 See Lilie Chouliaraki, The spectatorship of suffering (London: SAGE, 2006); Barbie Zelizer, About to die: How news images move the public (Chicago: University of Chicago Press, 2010); John Taylor, Body horror: Photojournalism, catastrophe and war (New York: NYUP, 1998); Luc Boltanski, Distant suffering: Morality, media and politics (Cambridge: CUP, 1999); Kari Andén-Papadopoulous, 'Body horror on the Internet: US soldiers recording the war in Iraq and Afghanistan', Media, Culture \& Society, 31/6 (2009), 921-38.

19 Ekaterina Balabanova \& Katy Parry, 'Introduction: Communicating war', Journal of War \& Culture Studies, 7/1 (2014), 1-4, quote at 1.

20 Some important contributions are Barbie Zelizer \& Keren Tenenboim-Greenblatt (eds.), Journalism and memory (Houndmills: Palgrave Macmillan, 2014); Astrid Erll \& Ann Rigney (eds.), Mediation, remediation, and the dynamics of cultural memory (Berlin: Walter de Gruyter, 2012); Joanne Garde-Hansen, Media and memory (Edinburgh: EUP, 2011); Motti Neiger et al., On media memory: Collective memory in a new media age (Houndmills: Palgrave Macmillan, 2011); Marita Sturken, Tangled memories: JFK, the Vietnam war and the politics of remembering (Berkeley \& Los Angeles: University of California Press, 1997); Barbie Zelizer \& Stuart Allan (eds.), Journalism after September 11 (London: Routledge, 2002); David Williams, Memory, media and the First World War (Quebec: McGill-Queen's University Press, 2009). 
21 Marie Cronqvist, 'Medier och minnen', Scandia, 79/1 (2013), 123-32.

22 Marie-Laure Ryan \& Jan-Noël Thon (eds.), Story-worlds across media: Toward a media-conscious narratology (Lincoln, Neb.: University of Nebraska Press, 2014); see also Leif Dahlberg \& Pelle Snickars (eds.), Berättande i olika medier (Stockholm: Statens ljud- och bildarkiv, 2008).

23 Roger Silverstone, 'Mediation and communication', in G. Calhoun et al. (eds.), The Sage handbook of sociology (London: SAGE, 2005), 188-207.

24 Silverstone 2005. Quote from Nick Couldry, 'Mediatization or mediation? Alternative understandings of the emergent space of digital storytelling', New Media \& Society, 10/3 (2008), 375.

25 Anders Ekström et al. (eds.), History of participatory media: Politics and publics, 1700-2000 (London: Routledge, 2012).

26 Chouliaraki 2006, 19; Roger Silverstone, Media and Morality: On the rise of the Mediapolis (Cambridge: Polity Press, 2006); Lilie Chouliaraki \& Shani Orgad, 'Proper distance: Mediation, ethics, otherness', International Journal of Cultural Studies, 14/4 (2011), 341-345.

27 Richard Huntington \& Peter Metcalf, Celebrations of death: The anthropology of mortuary ritual (Cambridge: CUP, 1979) covers the research on the role of death and suffering in the modern media landscape. A central argument often refers to the seminal work by Philippe Ariès, The hour of our death: The classic history of Western attitudes towards death over the last thousand years (New York: Vintage, 1982), including Anja Hirdman, Döden i medierna: våld, tröst, fascination (Stockholm: Carlssons, 2012); Louise Nilsson \& Mathias Persson (eds.), Den mediala döden: idéhistoriska variationer (Lund: Ellerström, 2008). The argument is that our own factual death-at least in the Western world-is more distant than ever before, but mediated death has gained cultural importance, pushing aside religion as the main interpreter of death's significance.

28 Thomas W. Laqueur, The work of the dead: A cultural history of mortal remains (Princeton: PUP, 2015).

\section{References}

Andén-Papadopoulous, Kari, 'Body horror on the Internet: US soldiers recording the war in Iraq and Afghanistan', Media, Culture \& Society, 31/6 (2009), 921-38. Ariès, Philippe, The hour of our death: The classic history of Western attitudes towards death over the last thousand years (New York: Vintage Books, 1982).

Audoin-Rouzeau, Stéphane \& Annette Becker, 14-18: Understanding the Great War (New York: Hill \& Wang, 2002).

Balabanova, Ekaterina \& Katy Parry, 'Introduction: Communicating war', Journal of War \& Culture Studies, 7/1 (2014), 1-4.

- - The media and human rights: The cosmopolitan promise (London: Routledge, 2014).

Bartov, Omer, Mirrors of destruction: War, genocide, and modern identity (Oxford: OUP, 2002). 
Bly, Robert, The half-finished heaven: the best poems of Tomas Tranströmer (Saint Paul: Graywolf, 2001).

Boltanski, Luc, Distant suffering: Morality, media and politics (Cambridge: CUP, 1999). Bourke, Joanna, Dismembering the male: Men's bodies, Britain and the Great War (Chicago: University of Chicago Press, 1996).

- - An intimate history of killing: Face-to-face killing in twentieth-century warfare (London: Basic, 1999).

- - Deep violence: military violence, war play, and the social life of weapons (Berkeley: Counterpoint, 2015).

Bryld, Claus \& Anette Warring, Besattelsetiden som kollektiv erindring (Roskilde: Roskilde Universitetsforlag, 1999).

Burke, Peter \& Asa Briggs, A social history of the media: from Gutenberg to the Internet (Cambridge: Polity, 2009).

Butler, Judith, Frames of war: When is life grievable? (London: Verso, 2009).

Chouliaraki, Lilie, The spectatorship of suffering (London: SAGE, 2006).

Chouliaraki, Lilie \& Shani Orgad, 'Proper distance: Mediation, ethics, otherness', International Journal of Cultural Studies, 14/4 (2011), 341-345.

Couldry, Nick, 'Mediatization or mediation? Alternative understandings of the emergent space of digital storytelling', New Media \& Society, 10/3 (2008), 373-391.

Cronqvist, Marie, 'Medier och minnen', Scandia 79/1 (2013), 123-32.

- - Patrik Lundell \& Johan Jarlbrink (eds.), Mediehistoriska vändningar (Lund: Mediehistoriskt arkiv, 2014).

Cultural History of Modern War [series], http://www.manchesteruniversitypress. co.uk/series/cultural-history-of-modern-war/ (accessed 20 December 2017).

Dahlberg, Leif \& Pelle Snickars (eds.), Berättande i olika medier (Stockholm: Statens ljud- och bildarkiv, 2008).

Dawes, James, Samantha Gupta \& C. Jayasinghe, 'On narrative and human rights', Humanity, 5/1 (2014), 149-56.

Dias, Susana Sampaio, Reporting humans rights (New York: Peter Lang, 2016).

Ekström, Anders, Solveig Jülich, Frans Lundgren \& Per Wisselgren (eds.), History of participatory media: Politics and publics, 1700-2000 (London: Routledge, 2012).

Enloe, Cynthia, Nimo's war, Emma's war: Making feminist sense of the Iraq War (Berkeley \& Los Angeles: University of California Press, 2010).

Erll, Astrid \& Ann Rigney (eds.), Mediation, remediation, and the dynamics of cultural memory (Berlin: Walter de Gruyter, 2012).

Evans, Martin, 'Opening up the battlefield: War studies and the cultural turn', Journal of War \& Culture Studies, 1/1 (2007), 47-51.

Fehrenbach, Heide \& Davide Rodogno (eds.), Humanitarian photography: A history (Cambridge: CUP, 2015).

Flacke, Monika (ed.), Mythen der Nationen: 1945-Arena der Erinnerungen: Eine Ausstellung des Deutsches Historisches Museums, 2 vols (Berlin: Deutsches Historisches Museum, 2004).

Garde-Hansen, Joanne, Media and memory (Edinburgh: EUP, 2011).

Gies, Lieve, Mediating human rights: Media, culture and human rights law (Abingdon: Routledge, 2014). 
Gitelman, Lisa, Always already new: Media, history, and the data of culture (Cambridge, Mass.: MIT, 2006).

Hirdman, Anja (ed.), Döden i medierna: Våld, tröst, fascination (Stockholm: Carlssons, 2012).

Hunt, Lynn, Inventing human rights: A history (New York: W. W. Norton, 2007).

Huntington, Richard \& Peter Metcalf, Celebrations of death: The anthropology of mortuary ritual (Cambridge: CUP, 1979).

'Journal of War and Culture Studies: Aims and Scope, http://www.tandfonline.com/ action/journalInformation? show=aimsScope\&journalCode $=y w a c 20$ (accessed 20 Dec. 2017).

Jülich, Solveig, Patrik Lundell \& Pelle Snickars (eds.), Mediernas kulturhistoria (Stockholm: Statens ljud- och bildarkiv, 2008).

Karlsson, Klas-Göran \& Ulf Zander (eds.), Echoes of the Holocaust: Historical cultures in contemporary Europe (Lund: Nordic Academic Press, 2003).

Kelly, Debra, 'Editorial: War! What is it good for? The work of the Group for War and Culture Studies', Journal of War \& Culture Studies, 1/1 (2007), 3-7.

Laqueur, Thomas W., The work of the dead: A cultural history of mortal remains (Princeton: PUP, 2015).

McSorley, Kevin, 'War and the body', in id. (ed.), War and the body: Militarisation, practice and experience (London: Routledge, 2013), 1-32.

Neiger, Motti, Oren Meyers \& Eyal Zandberg, On media memory: Collective memory in a new media age (Houndmills: Palgrave Macmillan, 2011).

Nilsson, Louise \& Mathias Persson (eds.), Den mediala döden: Idéhistoriska variationer (Lund: Ellerström, 2008).

Nora, Pierre, Les lieux de mémoire, 3 vols (Paris: Gallimard, 1984-6).

Ryan, Marie-Laure \& Jan-Noël Thon (eds.), Story-worlds across media: Toward a media-conscious narratology (Lincoln, Neb.: University of Nebraska Press, 2014).

Saunders, Nicholas J. \& Paul Cornish (eds.), Bodies in conflict: Corporeality, materiality and transformation (Abingdon: Routledge, 2014).

- _ - (eds.), Modern conflict and the senses (Abingdon: Routledge, 2017).

Scarry, Elaine, The body in pain: The making and unmaking of the world (New York: OUP, 1985).

Silverstone, Roger, 'Mediation and communication', in Craig Calhoun, Chris Rojek \& Bryan S. Turner (eds.), The Sage handbook of sociology (London: SAGE, 2005), $188-207$.

- - Media and Morality: On the rise of the Mediapolis (Cambridge: Polity Press, 2006).

Sjoberg, Laura, Gendering global conflict: Towards a feminist theory of war (New York: Columbia University Press, 2012).

- - Gender, war and conflict (Cambridge: Polity, 2014).

Sliwinski, Sharon, Human rights in camera (Chicago: University of Chicago Press, 2011).

Studies in the Social and Cultural History of Modern Warfare [series], https://www. cambridge.org/core/series/studies-in-the-social-and-cultural-history-of-modern-warfare/91ECDBDF57DFAFCE48A1E71899E2A80E (accessed 20 Dec. 2017). 
Sturken, Marita, Tangled memories: JFK, the Vietnam War and the politics of remembering (Berkeley \& Los Angeles: University of California Press, 1997).

Sylvester, Christine (ed.), Experiencing war (London: Routledge, 2011).

- War as experience: Contributions from international relations and feminist analysis (London: Routledge, 2013).

Taylor, John, Body horror: Photojournalism, catastrophe and war (Manchester: MUP, 1998).

Trodman, Dan, 'Foreword', in Nicholas J. Saunders \& Paul Cornish (eds.), Bodies in conflict: Corporeality, materiality, and transformation (New York: Routledge, 2014), xv-xix.

Williams, David, Media, memory and the First World War (Quebec: McGill-Queen's University Press, 2009).

Winter, Jay, Sites of memory, sites of mourning: The Great War in European cultural history (Cambridge: CUP, 1995).

- - (ed.), War and remembrance in the twentieth century (Cambridge: CUP, 1999).

- - Remembering war: The Great War between memory and history in the twentieth century (New Haven: Yale University Press, 2006).

-_Efrat Ben-Ze'ev \& Ruth Ginio (eds.), Shadows of war: A social history of silence in the twentieth century (New Haven: Yale University Press, 2010).

Zelizer, Barbie \& Stuart Allan (eds.), Journalism after September 11 (London: Routledge, 2002).

- - About to die: How news images move the public (New York: OUP, 2010).

- - \& Keren Tenenboim-Greenblatt (eds.), Journalism and memory (Houndmills: Palgrave Macmillan, 2014). 